\title{
INTEGRITAS BERPERILAKU KUDUS BERDASARKAN 1 PETRUS 1:13-25 TERHADAP KOMITMEN PELAYANAN PADUAN SUARA ADONAI
}

\author{
Frieska Putrima Tadung* \\ Sekolah Tinggi Teologi Bethel Indonesia \\ *friskaputrima@gmail.com
}

\begin{abstract}
Integrity to behave holy is a life that shows as befits the family of God, which is to live a life that matches the calling. A life that should be "blameless, a life of moral integrity and complete surrender. The purpose of this paper is to answer the question: What does Integrity mean is holy? how to prove the integrity of holy behavior is very important as a servant of God and in order to be able to create God's servants who have honesty and pleasing before God? how to prove that the impact of integrity behaving holy towards commitment in service is needed by choir service and in order to create maximum service that pleases God? The research method used is qualitative using a grounded research design. The results of the study are (1) Integrity is a picture of a person who has quality in all dimensions of his life. (2) how to prove the integrity of holy behavior is very important as a servant of God and in order to be able to create servants of God who have honesty and are pleasing before God; (3) Integrity of Holy Behavior in Creating God's Servant who Does Not Obey Lust, Living in Fear of God, and Behaving in Truth Obedient Haw Lust is an earthly system that is contrary to God's plan.
\end{abstract}

Keywords: Integrity; holy; commitment.

\begin{abstract}
Abstrak
Integritas berperilaku kudus merupakan kehidupan yang menunjukkan sebagaimana layaknya keluarga Allah, yakni menjalani kehidupan yang berpapadan dengan panggilan. Kehidupan yang seharusnya "tidak bercacat, kehidupan yang berintegritas moral dan penyerahan yang seutuhnya. Tujuan penulisan ini menjawa pertanyaan: Apakah yang dimaksud dengan Integritas berlaku kudus ? bagaimana membuktikan integritas berperilaku kudus sangatlah penting sebagai seorang pelayan Tuhan dan guna untuk dapat menciptakan pelayan Tuhan yang memiliki kejujuran dan berkenan di hadapan Tuhan? bagaimana membuktikan bahwa dampak integritas berperilaku kudus terhadap komitmen dalam pelayanan sangat dibutuhkan oleh pelayanan paduan suara dan guna untuk menciptakan pelayanan yang maksimal dan menyenangkan hati Tuhan? Metode peneltian yang digunakan adalah kualitatif ini menggunakan desain penelitian grounded. Hasil penelitian adalah (1) Integritas merupakan gambaran seorang pribadi yang memiliki kualitas diri dalam segala dimensi kehidupannya. (2) bagaimana membuktikan integritas berperilaku kudus sangatlah penting sebagai seorang pelayan Tuhan dan guna untuk dapat menciptakan pelayan Tuhan yang memiliki kejujuran dan berkenan di hadapan Tuhan; (3) Integritas Berperilaku Kudus dalam Menciptakan Pelayan Tuhan yang Tidak Menuruti Hawa Nafsu, Hidup dalam Takut akan Tuhan, dan Berperilaku Taat Kebenaran Haw Nafsu yaitu sistem duniawi yang bertentangan dengan rencana Allah.
\end{abstract}

Kata Kunci: integritas; kudus; komitmen 


\section{PENDAHULUAN}

Kekudusan merupakan sifat yang paling utama dari antara sifat-sifat Allah. Dari antara unsur-unsur kodrat Allah yang paling utama adalah bahwa Dia itu kudus. ${ }^{1}$ Kekudusan dalam Perjanjian Lama digunakan atas orang yang dinobatkan bagi maksud-maksud agamawi. ${ }^{2}$

Allah menentukan suatu tempat dan suatu proses ibadat bagi Israel yang disebut Tabernakel. Kemah suci dirancang supaya Israel tahu siapa Allah itu: untuk memberi tahu mereka bahwa Dia itu berbeda dengan mereka, namun la ingin ada bersama mereka. Ia lain dari umat-Nya, namun la ingin berelasi dengan mereka. Kemah suci mempunyai tiga bagian berbeda, yang dipisahkan oleh tiga tirai. Satu tirai bergantung di luar pintu masuk menuju halaman. Tirai yang lain menutup pintu masuk ke tempat kudus di mana kurbankurban dipersembahkan. Pintu masuk ketiga yang tertutup adalah yang menuju Tempat Mahakudus, tempat Allah selalu hadir. Hanya imam besar diperbolehkan masuk ke dalamnya, itu pun hanya sekali setahun. Tetapi bahkan imam besar tidak bisa melewati begitu saja bagian-bagian yang lebih luar dari kemah suci sebelum masuk kehadirat Allah. ${ }^{3}$ Para imam besar harus kudus untuk dapat masuk ke hadirat Allah.

Orang Kristen ketika bertemu dengan Allah yang kudus orang Kristen harus rnenyesuaikan diri. Kalau orang Kristen bisa memahami kekudusan Allah, maka sesuatu harus terjadi. Kalau orang Kristen berhadapan muka dengan Allah, la akan mempengaruhi harga diri orang Kristen

${ }^{1}$ Tony Evans, Teologi Allah Allah kita Maha Agung (Malang: Gandum Mas, 1999), 88.

${ }^{2}$ J.D. Douglas, Ensiklopedia Alkitab Masa Kini (Jakarta: Yayasan Bina Komunikasi, 2009), 617. tersebut. Orang Kristen harus menguduskan nama-Nya. ${ }^{4}$

Suatu hal yang berulang-ulang ditekankan dalam Alkitab ialah bahwa orang percaya harus seperti Allah. Jadi, karena Allah adalah kudus, orang yang menjadi pengikut bahkan pelayan Tuhan harus juga kudus. Allah secara pribadi bukan saja bebas dari semua kejahatan moral. Allah juga tidak dapat membiarkan adanya kejahatan. Oleh karena itu semua orang yang menjadi milikNya harus juga berusaha mencapai kekudusan yang merupakan sifat Allah yang begitu mendasar. ${ }^{5}$

Kekudusan hidup harus menjadi perhatian yang penting bagi setiap pelayan Tuhan. Akibat ketidakkudusan yaitu secara vertikal akan berdampak kepada pelayan Tuhan tersebut yang akan merasa bersalah dan tidak layak melayani Tuhan, begitu juga secara horizontal dampaknya tidak terlalu keliatan, karena biasanya di depan manusia para pelayan Tuhan pandai menutup-nutupin keadaan rohani yang sebenarnya memakai topeng rohani, namun sepandai-pandainya pelayan Tuhan menutupinya dihadapan manusia, pelayan Tuhan tersebut tidak dapat menutupinya di hadapan Tuhan".

Tujuan penulisan artikel ini untuk menjawab pertanyaan sebagai berikut: (1) Apakah yang dimaksud dengan Integritas berlaku kudus? Bagaimanakah membuktikan integritas berperilaku kudus sangatlah penting sebagai seorang pelayan Tuhan dan guna untuk dapat menciptakan pelayan Tuhan yang memiliki kejujuran dan berkenan di hadapan Tuhan? Bagaimanakah membuktikan bahwa dampak integritas Agung, 99.

${ }^{3}$ Tony Evans, Teologi Allah Allah kita Maha

${ }^{4}$ Ibid, 94.

${ }^{5}$ Millard J. Erickson, Teologi Kristen Volume Satu (Malang: Gandum Mas, 2005), 370. 
berperilaku kudus terhadap komitmen dalam pelayanan sangat dibutuhkan oleh pelayanan paduan suara dan guna untuk menciptakan pelayanan yang maksimal dan menyenangkan hati Tuhan?

\section{METODE PENELITIAN}

Penelitian kualitatif ini menggunakan desain penelitian grounded. Penelitian grounded adalah satu model desain penelitian yang dikhususkan untuk menemukan atau menghasilkan teori dari sutau fenomena yang berkaitan dengan situasi tertentu. Situasi yang dimaksud adalah suatu keadaan ketika individu (subjek penelitian) berinteraksi langsung, mengambil bagian dan melebur berproses menjadi satu terhadap suatu fenomena. Dalam penelitian grounded desain pengumpulan data adalah peneliti langsung kelapangan dan semuanya dilaksanakan di lapangan. Rumusan masalah ditemukan di lapangan, hipotesis senantiasa jatuh bangun ditempa data. Data merupakan sumber teori. Teori berdasarkan data sehingga teori juga lahir dan berkembang di lapangan. Jenis penelitiannya adalah suatu model dalam penelitian kualitatif dan yang bersifat konseptual atau teori sebagai hasil pemikiran induktif, bukan hasil pengembangan teori yang telah ada. ${ }^{6}$ Model penelitian grounded menggunakan proses berpikir induktif, beranjak dari data dan mengalir pada teoriteori baru. ${ }^{7}$ Teknik pengumpulan data adalah metode yang digunakan peneliti untuk mengumpulkan data-data yang diperlukan dalam penelitian. Dalam penelitian kualitatif

\footnotetext{
${ }^{6}$ Haris Herdiansyah, Metodelogi Penelitian Kualitatif Seni Dalam Memahami Fenomena Sosial (Jakarta: Salemba Humanika, 2009), 70.

${ }^{7}$ Stuart A. Schlegel, Penelitian Grounded dalam Ilmu-Ilmu sosial (Surakarta: FISIP UNS, 1984), 2.
}

teknik pengumpulan data yang utama adalah observasi participant, wawancara mendalam studi dokumentasi, dan gabungan ketiganya atau trianggulasi. ${ }^{8}$

Peneliti memutuskan menggunakan teknik-teknik pengambilan data sebagai berikut: Pertama, untuk menemukan makna integritas berperilaku kudus pada, maka peneliti menggunakan teknik pengumpulan data lewat metode hasil eksposisi ayat 1 Petrus 1:13-25. Eksposisi adalah penguraian hasil eksegesis yang telah dilakukan. ${ }^{9} \mathrm{Kedua}$, untuk menemukan dampak integritas berperilaku kudus dari anggota paduan suara, maka peneliti menggunakan teknik pengumpulan data metode wawancara kepada beberapa orang pelayan paduan suara. Metode wawancara atau biasa disebut dengan metode interview. ${ }^{10}$

Data hasil penelitian dianalisis dengan cara analisis domain (domain analysis), analisis taksonomik (taxonomic analysis), analisis komponensial (componential analysis) dan analisis tema kultural (discovering cultural themes Analysis). Analisis data meliputi tahap memasuki lapangan dengan grand-lour dan mini-tour question, analisis datanya dengan analisis domain. Tahap ke dua adalah menentukan fokus, teknik pengumpulan data dengan mini-tour question, analisis data dilakukan dengan analisis taksonomi. Selanjutnya pada tahap selection, pertanyaan yang digunakan adalah pertanyaan struktural, analisis data dengan analisis komponensial.

\footnotetext{
${ }^{8}$ Sugiyono, Metode Penelitian Pendidikan Pendekatan Kuantitaif, Kualitatif dan $R \& D$ (Bandung: Alfabeta, 2010), 412.

${ }^{9}$ http://www.sabda.org/learning/baca.php?b= hermeneutik, diakses pada hari Kamis tanggal 9 Maret 2017 pukul 13:48.

${ }^{10}$ Burhan Bungin, Metodologi Penelitian Sosial, 133-134.
} 
Setelah analisis komponensial dilajutkan analisis tema. ${ }^{11}$

\section{PEMBAHASAN}

\section{Pengertian Integritas Berperilaku Kudus}

Kata "integrity" yang berarti integritas merupakan aspek moral seorang pribadi. Artinya adalah "moral soundness and probity" (moral yang dapat diandalkan dan kejujuran). Hal itu terwujud dalam karakter pribadi yang utuh ("wholenss") dan lengkap ("completeness"). Kata "integrity" juga dapat bermakna "the quality or state of being unimpaired" (kualitas atau kondisi pribadi yang teguh (tidak lemah). ${ }^{12}$ Sedangkan kata "integrity" diartikan atau diberi makna ke dalam bahasa Indonesia sebagai satu karakter pribadi. Karakter itu adalah "kejujuran", "keterpaduan", "kebulatan" dan "keutuhan". ${ }^{3}$ Inti dari pengertian kata "integrity" adalah seperti yang diartikan oleh Kerby Anderson: "integrity and implies a wholencess person" (integritas menyatakan seorang pribadi yang utuh). Orang yang berintegritas adalah orang yang jujur dan bermoral teguh. ${ }^{14}$

Dimensi kata Latin "integrity" mempunyai cakupan yang luas. Tidak hanya keutuhan aspek lahiriah tetapi hal yang lebih penting atau mendasar adalah moral, etika, dan karakter yang mulia atau sering disebut dengan "noble character". Kejujuran moral tersebut tidak bisa dipisahkan dengan level moral seseorang. Integritas berakar pada moral seseorang. Orang yang berintegritas senantiasa berusaha bertindak berdasarkan prinsip-prinsip kebenaran yang normatif. ${ }^{15}$

\footnotetext{
${ }^{11}$ Sugiyono, Metode Penelitian Pendidikan Pendekatan Kuantitaif, Kualitatif dan R\&D, 413.

${ }^{12}$ Donald O. Bolander, New Webster's Dictionary and Thesaurus of the English Language (New York: Lexicon Publications INC, 1991), 502.

${ }^{13}$ Peter Salim dan Yenny Salim, Kamus Bahasa Indonesia Kontemporer (Jakarta: Modern English Press, 1995), 574.
}

Integritas Berperilaku Kudus berdasarkan 1 Petrus 1:13-25

Berhubungan dengan penelitian ini, di dalam 1 Petrus 1:13-25, ditemukan hal yang menjelaskan mengenai perilaku kudus yang harus menjadi pedoman utama untuk membentuk perilaku yang kudus. Untuk mencapai perilaku kudus harus didasari dengan karakter yang berintegritas. Integritas dalam bahasa Ibrani yaitu $(\text { iōm })^{16}$ yang adalah kata benda umum maskulin tunggal mutlak, yang memiliki arti lainnya yaitu tidak bersalah, keadaan atau kondisi kebaikan moral dalam kehidupan, dengan fokus tidak memiliki rasa bersalah atau dosa (2Sam. 15:11; Ayb. 4: 6; Mzm. 7: 9; 25:21; 26:1, 11; 41:13; Ams. 2: 7; 10:9, 29; 13: 6; 19: $1 ; 20: 7 ; 28: 6)$. Keadaan atau kondisi derajat lengkap, menyiratkan intensitas dalam tindakan (Ayb. 21:23; Yes. 47:9); terjadi secara acak, terjadinya tindakan yang kebetulan tanpa tujuan tertentu oleh seseorang, sehingga memiliki atau menjadi penampilan kesempatan (1Raj. 22:34; 2Taw. 18:33); hati nurani, yaitu, keadaan integritas dan kemurnian moral sehingga tidak bersalah, salah melakukan atau dosa, dengan fokus pada respon batin, bersih secara moral ini (Kej. 20:5-6; 1Raj. 9:4; Mzm. 78:72; 101:2). ${ }^{17}$

Selain (tōm), integritas disebut juga (tummâ) dalam bahasa Ibrani yang berarti saleh, jujur, menjauhi kejahatan dan ketulusan (Ayb 2:3; Ams. 11:3). Disebut juga $\mathrm{t}^{1} \mathrm{~m}$ yang berarti sempurna. Kata ini dari tiga belas kejadian diterjemahkan sembilan kali.

\footnotetext{
${ }^{14}$ Yosafat Bangun, Integritas Pemimpin Pastoral (Yogyakarta: ANDI, 2010), 89.

${ }^{15}$ Ibid, 90.

${ }^{16}$ Bible Works 8, Analisa kata sis strong's data for $<08537>$ [CD-ROOM].

${ }^{17}$ Swanson, J, Kamus Alkitab Dictionary of Biblical Languages with Semantic Domains: Hebrew (Old Testament), [CD-ROOM] (Logos, 1997).
} 
Biasanya kata ini mengacu pada pribadi Ayub. Kata ini diterjemahkan juga bersih, murni, tanpa cela, jujur dan tulus. Selain itu

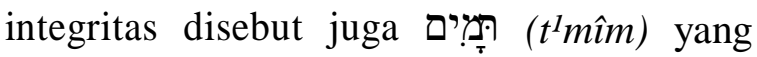
berarti menyeluruh atau lengkap. Kata ini mengacu pada hewan yang tidak bercela, diterjemahkan juga sebagai kata sifat terkait seperti penuh, utuh, tegak dan sempurna. Hal itu merupakan standar Ilahi untuk pencapaian manusia dalam mencari korban persembahan. ${ }^{18}$

Kata "integritas" tidak terdapat dalam Perjanjian Baru, namun kata yang setara dengan kata ini dapat dilihat pada "ketulusan", "kebenaran", "kemurnian (hati yang murni)", "satu mata", dll. Dalam arti di atas kesederhanaan itu setara dengan jujur, tulus, dan merupakan dasar untuk karakter sejati. ${ }^{19}$ Ketulusan atau kemurnian disebut dengan عì $1 \kappa \rho i ́ v \varepsilon 1 \alpha$ (eilikrineia) yang berarti ketegasan atau kemurnian yang dibagi menjadi kemurnian moral dan integritas. ${ }^{20}$

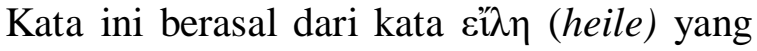
berarti kehangatan atau cahaya dari matahari,

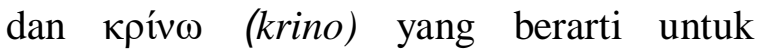
menguji. Kata-kata ini berarti "tested by sunlight", "pure" and "purity" (teruji oleh sinar matahari, yaitu murni dan kemurnian). Dalam Perjanjian Baru kata ini mengacu pada kejujuran/ketulusan dan kemurnian moral (Flp. 1:10; 2Ptr. 3:1; 1Kor. 5:8; 2Kor. $1: 12 ; 2: 17) .^{21}$

Dalam Perjanjian Baru integritas memiliki level kearifan atau kecerdikan dari

\footnotetext{
${ }^{18}$ Harris, Theological Dictionary of the Old Testament (Eerdmans: Abridged edition, 1985). Bible Works 8 [CD-ROOM]. [CD-ROOM].

${ }^{19}$ ISBE Bible Dictionary. Bible Works 8

${ }^{20}$ Barbara Friberg and Neva F. Mille, Analytical Greek Lexicon (Trafford Publishing, 2005). Bible Works 8 [CD-ROOM]
}

kehendak Allah dalam kehidupan. Perjanjian Baru salah satu isi khotbah Tuhan Yesus di atas bukit adalah "berbahagialah orang yang suci hatinya" (Mat. 5:8), hal itu secara langsung menyatakakan "an undividedness in following Gods commands" (dengan sepenuh hati mengikuti perintah-perintah Tuhan). Integritas tidak hanya berimplikasi tidak terbagi atau utuh tetapi lebih mengandung arti suatu kemurnian moral. ${ }^{22}$ Hal yang dituntut adalah sikap dari orangorang yang berintegritas untuk menjadi murid yang selalu belajar firman Tuhan. Kitab Yakobus memperingatkan supaya menjadi "pelaku firman", dan tidak hanya pendengar saja (Yak. 1:22). ${ }^{23}$ Dalam perspektif Alkitab, kehidupan yang berintegritas bersumber dari kedewasaan rohani dan psikologis. "Moral integrity is felt as a fruit of the Spirit and sanctified through God's grace" (Integritas moral dirasakan sebagai buah Roh dan disucikan melalui anugerah Allah). ${ }^{24}$

Kehidupan yang berintegritas adalah kehidupan dalam segala aspeknya yang memiliki beragam variasi yang terjalin secara harmoni. Integritas juga menyatakan kehidupan yang memiliki kesatuan (unity). Utuh dan segalahnya menjadi kesatuan. Dengan demikian dapat dikatakan seorang yang memiliki moralitas integratif adalah mereka yang menghidupi hidup ini dengan segala dimensinya (yang imanen dan transenden) secara utuh. Mereka bukan orang-orang yang memiliki kepribadian yang

\footnotetext{
${ }^{21}$ Gerhard Kittel, Theological Dictionary of the New Testament (Eerdmans: Abridged edition, 1985). Bible Works 8 [CD-ROOM]

${ }^{22}$ Bangun, Integritas Pemimpin Pastoral, 91.

${ }^{23}$ Ibid., 92.

${ }^{24}$ Leanne M. Olson, The Relationship Between Moral Integrity, Psychological Well-Being, and Anxiety, http://www.charis.wlc.edu/publications/charis_spring 02/01son.pdf.
} 
retak ("split personality"). Integritas: Secara historis telah dipahami mengandung arti yang sama. Arti utuh adalah orang yang berintegritas seperti angka yang utuh. Gambaran seorang pribadi yang utuh, seorang pribadi yang entah bagaimana tak terpecah-pecah".

Allen Walker Read mengatakan: "Constituting a completed whole. Constituting an essential part of a whole necessary for completeness; intrinsic" (merupakan suatu keseluruhan. Merupakan bagian penting dari keseluruhan yang diperlukan untuk kelengkapan, sangat hakiki atau fundamental). ${ }^{25}$ Integritas adalah gambaran seorang pribadi yang memiliki kualitas diri dalam segala dimensi kehidupannya. Seorang yang berintegritas memiliki pikiran yang utuh (cerdas, dalam dan luas), emosi yang stabil, kemauan yang teguh, tidak mudah menyerah, mampu berbagi hidup dengan orang lain, menaati aturan yang ada, berfokus pada nilai-nilai luhur agama dan kemanusiaan. ${ }^{26}$

Integritas mengandung arti bahwa orang yang lurus, jujur dan tulus. Bisa dipercaya karena adanya konsistensi kata, sifat dan tindakan. Inilah wujud luar dari integritas yang tertanam dalam batin. Seharusnya menunjukkan kehidupan sebagaimana layaknya keluarga Allah, yakni menjalani kehidupan yang berpapadan dengan panggilan. Kehidupan yang seperti itu haruslah "tidak bercacat, kehidupan yang berintegritas moral dan penyerahan yang seutuhnya”. Dalam kejadian 17 berarti lingkungan kehidupan "di hadapan-Nya", dalam 1 Tawarikh 29 berarti lingkungan

${ }^{25}$ Allen Walker Read, The New International Webster's Comprehensive Dictionary of the English Language (Napies, Florida: Trident Press International, 2003), 660.

${ }^{26}$ Bangun, Integritas Pemimpin Pastoral, 91. kehidupan di hadapan Allah yang "menguji hati”. Integritas adalah menjalani kehidupan yang tidak bercacat (kudus) yang disaksikan oleh Allah. ${ }^{27}$

Kekudusan dalam bahasa Yunani

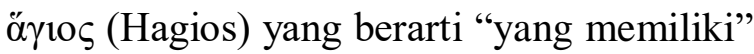
dasar pemikiran yang sama mengenai keterpisahan dan kesucian terhadap Allah. Kata "mahakudus" dalam Kisah Para Rasul 2:27 dan kata "kudus" dalam Wahyu 15:4 adalah terjemahan dari kata Yunani örios (Hagios) (di tempat lain diterjemahkan "suci" atau "saleh"), suatu kata yang mengandung arti hubungan yang benar dengan Allah, mungkin juga dalam pengertian kekasih. ${ }^{28}$

Kata ö $\gamma 10 \varsigma$ (Hagios) dalam istilah Yunani tua hagios menunjukkan objek kekaguman, yang kata sifat Hagios berarti "clean" yang diterjemahkan "bersih", dan kata kerja Hagios memiliki arti "to shrink from" yang diterjemahkan "menyusut dari atau bersembunyi". ö $\gamma 10 \varsigma$ (hagios) digunakan dari tempat-tempat suci (kudus) dan kemudian dewa dan praktik keagamaan, meskipun itu menjadi umum hanya dalam periode Helenistik. Kekudusan Allah pada dasar Perjanjian Lama, kekudusan Allah disini terlihat alam (Why. 4:8). Hal ini mencakup kemahakuasaan, keabadian, dan kemuliaan, dan membangkitkan kekaguman. Dalam Yohanes, Allah adalah Bapa yang Kudus (Yoh. 17:11). Allah memanggil orang yang kudus (1Ptr. 1:15-16).

Kekudusan dalam kata Ibrani disebutkan לקדש (Qadosh) yang berarti "ditentukan garis-garis batas" atau "ditarik dari pemakaian umum yang biasa". Kata ini

\footnotetext{
${ }^{27}$ Jonathan Lamb, Integritas Memimpin di Bawah Pengamatan TUHAN (Jakarta: Literatur Perkantas, 2008) 26-28.

${ }^{28}$ J.D. Douglas, Ensiklopedia Alkitab Masa Kini, 617.
} 
berasal dan kata kerja yang artinya "memutuskan" atau "memisahkan". ${ }^{29}$

Kekudusan berarti terpisah, dikhususkan, terpotong dari, dilepaskan seseorang atau benda, dan dikhususkan bagi Tuhan supaya Tuhan dapat memakainya. ${ }^{30}$ Pengertian kudus yang berarti dipisahkan mencakup dua hal yakni, dipisahkan dari halhal duniawi yang bertentangan dengan kehendak Allah, dan dikhususkan menjadi milik sang pembebas yaitu Allah (Im. 19:2). ${ }^{31}$

Kalau di kalangan agama bangsabangsa di sekitar Israel kata kudus dengan leluasa dipakai untuk berbagai benda dan perbuatan. Serta orang-orang yang terlibat dalam penyembahan, dalam ibadah perjanjian Israel istilah ini dipakai secara leluasa untuk Allah sendiri. ${ }^{32}$ Kudus (qadosh), sejak semula diarahkan untuk bidang keagamaan, misalnya: sebidang tanah, sebuah bangunan, peralatan dalam tempat ibadah, bahkan seekor kuda juga dapat dianggap kudus sejauh itu semua dikhususkan untuk maksud keagamaan dan peribadatan. ${ }^{33}$ Namun perasaan mengenai kuasa mengagumkan yang terdapat dalam benda-benda kudus ini tidak boleh disamakan dengan nilai-nilai moral dan etis. Kudus atau kekudusan merupakan suatu sifat orang atau sesuatu yang sepenuhnya sesuai dengan tujuan atau maksud keberadaannya yang bulat dan utuh.

Dalam perjanjian Lama yang termasuk ke dalam hukum kesucian (Im. 1726) sehingga ini menjadi pegangan sekaligus menjadi ajakan bagi orang-orang Israel untuk

\footnotetext{
${ }^{29}$ Erickson, Teologi Kristen Volume Satu, 368.

${ }^{30}$ Jackie A. Naude, Dictionary of Old Testament Theology \& Ekesegesis (Paternoster Press, 1996), 877.

${ }^{31}$ David L. Baker, Mari Mengenal Perjanjian Lama (Jakarta: BPK Gunung Mulia, 2002), 37.
}

menjadi Kudus, karena Allah mereka adalah Allah yang kudus (Im 19:2, 20:26). Selain benda, tempat upacara, kitab suci, hukum dan perjanjian juga dapat disebut kudus sejauh dikuduskan dan disucikan bagi Allah. ${ }^{34}$

Dari uraian diatas penulis menyimpulkan bahwa Pengertian Integritas Berperilaku Kudus yaitu; Integritas merupakan gambaran seorang pribadi yang memiliki kualitas diri dalam segala dimensi kehidupannya. Seorang yang berintegritas memiliki pikiran yang utuh (cerdas, dalam dan luas), emosi yang stabil, kemauan yang teguh, tidak mudah menyerah, mampu berbagi hidup dengan orang lain, menaati aturan yang ada, berfokus pada nilai-nilai luhur agama dan kemanusiaan. . Kudus atau kekudusan merupakan suatu sifat orang atau sesuatu yang sepenuhnya sesuai dengan tujuan atau maksud keberadaannya yang bulat dan utuh.

\section{Integritas Berperilaku Kudus dalam Menciptakan Pelayan Tuhan yang Tidak Menuruti Hawa Nafsu, Hidup dalam Takut akan Tuhan, dan Berperilaku Taat Kebenaran}

Berhubungan dengan penelitian ini, di dalam 1 Petrus 1:13-25, ditemukan hal yang menjelaskan mengenai integritas perilaku kudus yang harus menjadi pedoman terhadap pelayanan paduan suara Adonai di Gereja Bethany Nginden Surabaya. Dalam terjemahan Baru (ITB) dalam 1 Petrus 1:1516 dikatakan bahwa "Hendaklah kamu menjadi kudus di dalam seluruh hidupmu sama seperti Dia yang kudus, yang telah

\footnotetext{
368

${ }^{32}$ Erickson, Teologi Kristen Volume Satu,

${ }^{33}$ W.S. Lassor \& F.W. Bush, Pengantar Perjanjian Lama 1 (Jakarta: BPK Gunung Mulia, 2005), 215.

${ }^{34}$ Gerald O'Collins \& Edward G, Kamus Teologi (Yogyakarta: Kanisius, 1996), 174.
} 
memanggil kamu. Sebab ada tertulis: Kuduslah kamu, sebab Aku kudus". Dalam perikop ini ditemukan 4 hal untuk mencapai perilaku kudus, yaitu: Berperilaku tidak Menuruti Hawa Nafsu (1Ptr. 1:14), Berperilaku Hidup dalam Takut akan Tuhan (1Ptr. 1:17), dan Berperilaku Taat kepada Kebenaran (1Ptr. 1:22).

\section{Berperilaku tidak Menuruti Hawa Nafsu (1Ptr. 1:14)}

Pada ayat 14 terdapat kata $\dot{\pi} \pi \imath v \mu$ íars (epithumiais) berasal dari kata $\dot{\varepsilon} \pi \imath v \mu i ́ \alpha$ (epitumia) yang berarti desire dalam terjemahan bahasa Indonesia menyebutkan hasrat atau keinginan. Kata ini merupakan kata benda kasus datif bentuk feminim jamak. Kittel Bromiley mengemukakan bahwa kata ini menunjukkan keinginan akan makanan atau seks. Keinginan ini pada awalnya secara moral netral, tetapi filsafat memandang sebagai menjauhkan diri dari dunia indrawi dan menganggapnya sebagai tercela. Namun dalam Perjanjian Lama penggunaan kata ini lebih menunjukkan kepada "mengingini" sehingga mengutuk kejahatan akan serta tindakan kejahatan ini. Keinginan kadang-kadang dipandang sebagai dosa utama karena bertentangan dengan perintah Allah.

Dalam penggunaannya di Perjanjian Baru, kata ini menunjukkan rasa lapar (Luk. 15:16.), Kerinduan (Luk. 22:15.), atau keinginan untuk misteri ilahi (Mat. 13:17) atau untuk sesuatu yang baik (Flp. 1:23; 1Tim. 3:1). Tapi biasanya menunjukkan keinginan jahat juga seperti yang ditunjukkan oleh objek (seorang wanita di Mat. 5:28, halhal lain di Mrk. 4:19), dengan orientasi (Gal. $5: 17$ ), dengan instrumen ("hati" dalam Rm. 1:24, "tubuh" dalam Rm. 6:12, "daging"

${ }^{35}$ Charles Houser, Alkitab Edisi Studi (Jakarta: Lembaga Alkitab Indonesia, 2010), 2014. dalam Ef. 2:3, "mata" dalam 1Yoh. 2:16), atau dengan cara memenuhi ("keinginan daging" dalam 1Ptr. 2:11, keinginan duniawi dalam Tit. 2:12, "mencemarkan diri" dalam 2Ptr. 2:10, dll.). Keinginan jahat adalah manifestasi dari dosa.

Charles Houser dalam Alkitab edisi studi mengemukakan hawa nafsu dalam ayat ini yaitu keinginan dan perbuatan dosa di masa lampau, termasuk pesta pora dan penyembahan berhala. Hawa nafsu atau keinginan seperti "pesta pora" dan "perjamuan minum" menunjuk pada perjamuan-perjamuan yang banyak diselenggarakan oleh kelompok-kelompok dagang atau kelompok-kelompok lainnya di daerah Asia Kecil. ${ }^{35}$ Mungkin ada jemaat Kristen yang pernah menjadi anggota kelompok-kelompok ini, karena menganggapnya sebagai tempat yang baik untuk menjalin relasi sosial dan perdagangan, sehingga terpengaruh dengan perbuatanperbuatan yang demikian.

Cedar mengemukakan hawa nafsu yang dimaksud dalam ayat ini merupakan keinginan daging dan menentang kehidupan Roh (Gal. 5:17). Hawa nafsu adalah sistem duniawi yang bertentangan dengan rencana Allah bagi semua ciptaan-Nya (1Yoh. 2:1517), untuk tidak mematuhi Tuhan dan mengikuti hawa nafsu dan untuk membawa kembali kepada ketidaktahuan dan kebutaan rohani. Kehidupan kekudusan didasarkan pada keaktifan gaya hidup yang taat. Petrus memerintahkan untuk menjadi anak-anak yang taat. Ketaatan adalah di bagian paling dasar dari gaya hidup Kristen. Petrus memperingatkan untuk tidak hidup sesuai dengan keinginan yang seperti dulu ketika hidup dalam ketidaktahuan. Ketika orang 
percaya taat kepada-Nya, pasti tidak akan mengikuti dan hidup sesuai dengan hawa nafsu. ${ }^{36}$

Lange dan Schaff mengemukakan bahwa hawa nafsu bukan hanya sensual impuls dan keinginan, tetapi keinginan apa yang berbeda dari apa yang Tuhan ijinkan, keinginan jahat komprehensif yang dijelaskan oleh Yohanes (1Yoh. 2:16) sebagai keinginan daging, nafsu mata dan keangkuhan kehidupan (Gal. 5:19), hal ini juga termasuk ambisi, keinginan kekuasaan dan keinginan pengetahuan. Hawa nafsu lebih jelas didefinisikan oleh "ketidaktahuanmu". Dosa menggelapkan pemahaman oleh awan prasangka dan gagasan palsu (Rm. 1:21; Ef. 4:18) dan kebodohan di sisi lain merupakan induk dari banyak dosa. Sebuah petunjuk menemukan bahwa surat ini ditujukan kepada mantan kafir, yang tanpa kesadaran moral yang jelas, semua diskriminasi yang pasti antara baik dan jahat, antara benar dan salah; tetapi orang-orang Yahudi juga dibebankan dengan ketidaktahuan sebagai alasan mereka menolak Kristus (Kis. 3:17) dan sejauh mana kebingunan akan kesadaran moral dan tertutup oleh prinsip yang terkenal dari Sanhedrin. ${ }^{37}$

\section{Berperilaku Hidup dalam takut akan Tuhan} (1Ptr. 1:17)

Pada ayat 17 terdapat kata $\varphi o ́ \beta \omega$ (phobo) berasal dari kata póßos (phobos) yang berarti fear or reverence dalam terjemahan bahasa Indonesia menyebutkan

${ }^{36}$ P. A. Cedar, \& Ogilvie, L. J. Vol. 34: The Preacher's Commentary Series, Volume 34: James / 1 \& 2 Peter / Jude. (Nashville, Tennessee: Thomas Nelson Inc, 1984), 34.

${ }^{37}$ J. P. Lange, P. Schaff, Fronmller, G. F. C., \& J. I. Mombert, A Commentary on the Holy Scriptures: 1 Peter (Bellingham, WA: Logos Research Systems, Inc, 2008), 21. ketakutan atau penghormatan. Kata ini merupakan kata benda kasus datif bentuk maskulin tunggal. Makna kata ini yaitu yang dapat menimbulkan ketakutan akibat pemerintahan yang jahat (Rm. 13:3; 1Ptr. 3:14) kemudian dalam arti pasif akibat ketakutan yang gentar, ketakutan ketika melihat, ketakutan ketika mendengar bunyi (Mat. 28:4, 8; Luk. 1:12, 65; 1Ptr. 1:17) dan seperti ketakutan seorang budak (Rm. 8:15) selain itu ketakutan karena penghormatan atau respek sebagai rasa hormat (Kis. 9:31; Rm. 3:18; 1Ptr. 2:18). ${ }^{52}$

Kata Фóßos (phobos) digunakan karena kepanikan, ketakutan dalam menghadapi peristiwa yang tidak dimengerti, rasa takut sebagai sikap dasar terhadap Allah dan dalam hubungan ilahi dalam arti penghormatan dan merupakan akhir dari kecemasan sebelum menerima ancaman dan hukuman. Di sisi lain kata ini lebih sering mengacu pada reaksi batin atau emosi yang kemudian diikuti dengan tindakan tertentu atau pengembangan diri seperti: menangis karena ketakutan (Mat. 14:26), gemetar ketakutan (Mat. 28:4) dan pingsan karena ketakutan (Luk. 21:26). ${ }^{38}$

Menurut orang-orang Yunani dasar

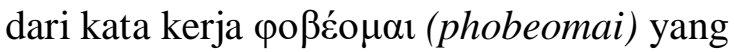
diterjemahkan "melarikan diri". Hal ini sebagai emosi yang berkembang dari tindakan, yang kaget dan disarankan untuk lari karena "takut". Kata ketakutan berasal

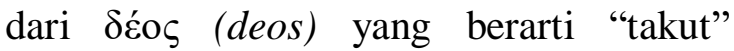
sementara póßos (phobos) adalah "ketakutan" atau "panik". Dalam

\footnotetext{
${ }^{38}$ Balz Schneider, Exegetical Dictionary of the New Testament (Eerdmans: Abridged edition, 1985). Bible Works 8 [CD-ROOM].
} 
penggunaannya biasa memiliki nuansa "kekuatiran", "keprihatinan", "kecemasan" dan "kekaguman". Selain itu dalam takhayul Yunani póßos (phobos) adalah dewa yang kuat, anak Ares, dan dewa perang. Sparta memiliki kuil. Dia digambarkan dalam bentuk ketakutaninspirasi yang mengaktualisasikan dewa yang disajikan oleh Homer. ${ }^{39}$

Cedar dan Ogilvie mengemukakan bahwa Petrus mengingatkan siapa Tuhan dan siapa manusia. Panggilan tertinggi manusia adalah untuk memberikan kesetiaan utama kepada Raja segala raja dan kerajaan-Nya. Ini adalah tempat tinggal sementara karena kewarganegaraan manusia yaitu dalam Kerajaan Allah yang kekal. Dalam konteks ini, Petrus memberitahukan bahwa Allah adalah hakim yang tidak memihak. Petrus menggunakan kata póßos (phobos) "takut" yang merupakan jenis ketakutan yang bukan untuk menunjukkan ketakutan yang disebabkan oleh penyakit emosional, namun ini adalah jenis ketakutan yang sehat. Ini adalah jenis ketakutan yang dijelaskan oleh Lukas dalam Kisah Para Rasul 2:43. Dalam terjemahan ini menunjukkan "kekaguman". Kagum atau ketakutan akan penghormatan dalam cara hidup di hadapan Tuhan. Manusia perlu hidup dalam pengakuan konstan siapa Tuhan dan siapa manusia. ${ }^{40}$

Black mengemukakan bahwa Petrus menggambarkan nuansa "takut" $\varphi o ́ ß o \varsigma$ (phobos) yang harus dimiliki seseorang ketika berbicara dengan Allah yang sesuai

${ }^{39}$ Gerhard Kittel, Theological Dictionary of the New Testament (Eerdmans: Abridged edition, 1985). Bible Works 8 [CD-ROOM].

${ }^{40}$ Cedar, PA, \& Ogilvie, LJ Vol.34: The Preacher ini Commentary Series, Volume 34: James / $1 \& 2$ Petrus /Jude, 125. sebagai orang Kristen. Dalam 1 Petrus, menggunakan kata "reverent fear" dan "reverence" (1Ptr. 3:2) dan "penghormatan" (1Ptr. 3:15). Sekali lagi analogi hubungan orang tua dan anak dapat membantu. Ada ketepatan dan tidaknya di mana seorang anak mungkin takut kepada orang tuanya. Orang Kristen seharusnya tidak hidup dalam ketakutan akan penghukuman, tetapi harus memiliki keyakinan di hadapan Allah. Namun demikian, harus hidup dalam panggilan "ketakutan karena hormat pada Tuhan". ${ }^{41}$

Berperilaku Taat kepada Kebenaran (1Ptr. 1:22)

Pada ayat 22 terdapat kata $\dot{\pi} \alpha \kappa o n ̃ n$ (hupakoe) yang berarti obedience dalam terjemahan bahasa Indonesia menyebutkan mematuhi atau menaati. Kata ini merupakan kata benda kasus datif bentuk feminim tunggal. Menurut Friberg kata ini diterjemahkan sebagai ketaatan, ketundukan dan kepatuhan (Rm. 16:19),

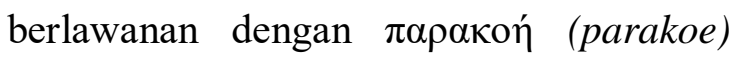
yaitu ketidaktaatan. ${ }^{42}$

Gerhard mengemukakan makna kata "mematuhi atau mentaati" digunakan dalam pengertian untuk istri, anak, dan pelayan atau pembantu (Ef. 6: 1, 5; Kol. 3:20, 22). Penggunaan LXX menunjukkan seberapa kuat ketaatan dari mendengarkan firman dan perkataan Tuhan (Kej. 22:18;. Yer. 13:10). Kata vंлíкoos (hypekoos) selalu menyiratkan keputusan agama (misalnya, terhadap ó $\mu \alpha \rho \tau i ́ \alpha \varsigma$ (hamartia) dalam Roma 6:16 dan $\pi \alpha \rho \alpha \kappa o \tilde{\varsigma}$ (parakoe) dalam Roma

${ }^{41}$ A. Black, \& M. C.Black, 1 \& 2 Peter. The College Press NIV Commentary (1 Pe 1:17) (Joplin, Mo: College Press Pub, 1998), 18.

${ }^{42}$ Barbara Friberg and Neva F. Mille, Analytical Greek Lexicon (Trafford Publishing, 2005). Bible Works 8 [CD-ROOM] 
5:19). Apa yang ditaati mungkin adalah kebenaran (1Ptr. 1:22) atau Kristus (2Kor. 10:5). Denotasi bukanlah sikap etis tetapi berasal dari tindakan taat (1Ptr. 1:14). Ketaatan iman ( $\mathrm{Rm} \mathrm{1:5;} \mathrm{16:26)} \mathrm{yang}$ menyiratkan bahwa pesan dari masalah iman dalam ketaatan, vं berarti "taat" kepada Allah (Kis. 7:39), rasul (2Kor. 2: 9). Kristus sendiri adalah ن் ஸ́коо (hypekoos) dalam memenuhi misi ilahi-Nya (Flp. 2: 8). ${ }^{43}$

Pada ayat ini juga terdapat kata $\dot{\alpha} \lambda \eta \theta$ cías (aletheias) berasal dari kata $\dot{\alpha} \lambda \eta \dot{\theta} \theta \varepsilon \dot{\alpha} \alpha$ (aletheia) yang berarti truth dalam terjemahan bahasa Indonesia menyebutkan kebenaran. Kata ini merupakan kata benda kasus genitif bentuk feminim tunggal. Secara etimologis $\dot{\alpha} \lambda \hat{\eta} \theta \varepsilon ı \alpha$ (aletheia) berarti "non concealment" yang diterjemahkan sebagai tanpa disembunyikan. Dengan demikian menunjukkan apa yang dilihat, diindikasikan, dinyatakan, atau diungkapkan, yaitu hal seperti apa adanya, tidak seperti yang tersembunyi atau dipalsukan. $\quad \dot{\alpha} \lambda \dot{\theta} \theta \varepsilon i \alpha$ (aletheia) adalah "keadaan yang sebenarnya" misalnya, kebenaran dalam hukum, dari kejadian nyata dalam sejarah, atau keberadaan yang benar dalam filsafat. Mengembangkan hubungannya dengan logos yang fungsinya adalah untuk mengungkapkan dan pistis karena salah satu dapat mengandalkan kebenaran dan juga dapat dipercaya ketika berbicara. sehingga $\dot{\alpha} \lambda \hat{\eta} \theta \varepsilon i \alpha$ (aletheia) dapat menunjukkan "keadaan yang sebenaranya" sebagai kualitas pribadi.

Friberg mengemukakan $\dot{\alpha} \lambda \hat{\eta} \theta \varepsilon 1 \alpha$ (aletheia), sebagai: (1) apa yang telah dipastian dan keabsahan (Ef. 4:21) dan

${ }^{43}$ Gerhard Kittel, Theological Dictionary of the New Testament (Eerdmans: Abridged edition, 1985). Bible Works 8 [CD-ROOM]. berlawanan dengan $\pi \lambda \alpha$ óv (plane) yang diartikan sesat atau mengembara. (2) keadaan sebenarnya, terutama seperti yang diungkapkan oleh Ilahi (Rom 1:18) dan berlawanan dengan $\mu \tilde{v} \theta o s$ (muthos) yang berarti fiksi atau mitos. (3) konsep yang mutlak (2Tes. 2:12). (4) fakta atau pernyataan yang benar pernyataan (Luk. 4:25) dan berlawanan dengan $\psi \varepsilon \tilde{\delta} \delta \circ \varsigma$ (psieudos) yang diartikan sebagai kebohongan atau kepalsuan. (5) apa yang ditandai dengan cinta akan kebenaran, kejujuran dan kesetiaan (1Kor. 5:8; 13:6) dan berlawanan dengan àdıía (adikia) yang berarti salah atau jahat. (6) realitas yang bertentangan dengan dalih atau penampilan belaka; ketulusan (Flp. 1:18) dan berlawanan dengan $\pi \rho o ́ \varphi \alpha \sigma i \varsigma$ (profasis) yang berarti dalih atau alasan. ${ }^{44}$

Elliott mengemukakan ketaatan kepada kebenaran yang Petrus bicarakan adalah penyampaian awal untuk mengklaim Injil. Dalam iman yang menyelamatkan kebenaran Allah yang didengar dan diperhatikan. "Ketaatan" disebutkan sebagai kualitas dari anak yang taat kepada Allah, yang konsisten seperti ketaatan Yesus Kristus (1Ptr. 1:2). Dalam 1 Petrus 1:14-16, "ketaatan" berhubungan dengan "kesucian" dan juga dengan "pemurnian" yang merupakan tanda sebagai tindakan yang membedakan orang-orang percaya yang dahulu dan merupakan gaya pra pertobatan hidup. Istilah $\dot{\alpha} \lambda \dot{\eta} \theta \varepsilon 1 \alpha$ (aletheia) "kebenaran" digunakan untuk menonjolkan "kasih karunia Allah" sebagai "kebenaran". Kebenaran berbeda dengan kebohongan atau kepalsuan yang tidak sesuai atau persis dengan kenyataan. Dalam conceptuality

${ }^{44}$ Barbara Friberg and Neva F. Mille, Analytical Greek Lexicon (Trafford Publishing, 2005). Bible Works 8 [CD-ROOM] 
Kristen, Tuhan Allah adalah "Bapa dari kebenaran", yang telah berbicara "firman kebenaran" di dalam Yesus Kristus dan Injil (Kol. 1:5; Ef. 1:13; 4:20). Dengan demikian, untuk menjadi seorang Kristen harus dibawa "oleh firman kebenaran" (Yak. 1:18) atau "memperoleh pengetahuan tentang kebenaran" (1Tim. 2: 4; 2Tim. 3: 7; Ibr. 10:26; 1Tim. 4:3) dan untuk diberikan tanggung jawab "menaati kebenaran" (Gal. 5: 7). ${ }^{45}$ MacArthur mengemukakan bahwa dalam bagian ini, Petrus tidak menghubungkan atau tidak merujuk kepada iman, yang tentunya dalam Perjanjian Baru sering menghubungkannya dengan keselamatan (1Ptr. 1:9; Kis. 14:27; 15:9; 20:21; 26:18; Rm. 3:22, 25-28; 4:5; 5:1; Gal. 2:16; 3:11, 24, 26; Ef. 2:8; Flp. 3:9; 2Tes. 2:13; 2Tim. 3:15). Namun, seiring dengan pembersihan dari dosa yang datang melalui iman yang menyelamatkan (Kis. 15:8-9), Petrus merujuk kepada ketaatan akan kebenaran, unsur yang melekat dari iman yang menyelamatkan (Yoh. 3:36; Rm. 10:10; Ef. 2:8-10; Ibr. 5:9; 11:1-34). Jadi Petrus tidak mengabaikan iman dalam kaitannya dengan keselamatan; dia hanya mendefinisikan iman. Petrus menegaskan untuk pembacanya bahwa mereka diselamatkan sesuai dengan rencana Allah Bapa, dengan kerja Roh Kudus, supaya taat kepada Yesus Kristus dan ditaburi dengan darah-Nya. Ketaatan bisa menjadi sinonim dari iman dalam Perjanjian Baru.

Iman bukanlah dimulai dari pekerjaan manusia tetapi dimulai dari ketaatan (Ef. 2:8) namun jika benar diberikan oleh Allah itu akan menghasilkan orang-orang percaya yang teratur menaati kebenaran (Yak. 1: 22-25; 2:14-26; 1Yoh. 2:3-6; 3:7-

${ }^{45}$ J. H. Elliott, 1 Peter: A New Translation with Introduction and Commentary (New Haven, London: Yale University Press, 2008), 383.
9, 24) dan mewujudkan kasih Allah kepada orang lain (1Yoh. 2: 10-11; 3: 10-11, 14-17; 4: $7-8,16,20){ }^{46}$

Dari uraian diatas penulis menyimpulkan bahwa Integritas Berperilaku Kudus dalam Menciptakan Pelayan Tuhan yang Tidak Menuruti Hawa Nafsu, Hidup dalam Takut akan Tuhan, dan Berperilaku Taat Kebenaran yaitu Hawa nafsu adalah sistem duniawi yang bertentangan dengan rencana Allah bagi semua ciptaan-Nya, hawa nafsu bukan hanya sensual impuls dan keinginan, tetapi keinginan apa yang berbeda dari apa yang Tuhan ijinkan, keinginan jahat. Takut berarti kepanikan, ketakutan dalam menghadapi peristiwa yang tidak dimengerti, rasa takut sebagai sikap dasar terhadap Allah dan dalam hubungan ilahi dalam arti penghormatan dan merupakan akhir dari kecemasan sebelum menerima ancaman dan hukuman. Ketaatan kepada kebenaran yang Petrus bicarakan adalah penyampaian awal untuk mengklaim Injil. Dalam iman yang menyelamatkan kebenaran Allah yang didengar dan diperhatikan. "Ketaatan" disebutkan sebagai kualitas dari anak yang taat kepada Allah, yang konsisten seperti ketaatan Yesus Kristus.

\section{Dampak Integritas Berperilaku Kudus Terhadap Komitmen dalam Pelayanan Suara Adonai}

Komitmen pelayanan paduan suara Adonai merupakan perjanjian untuk melakukan sesuatu baik dengan diri sendiri, orang lain atau juga suatu organisasi (gereja) untuk kemuliaan Tuhan lewat pujian dan penyembahan. Komitmen

${ }^{46}$ J. MacArthur, 1 Peter (Chicago: Moody Publishers, 2004), 89. 
meliputi pengertian secara alkitabiah terhadap pelayanan paduan suara yang dilakukan dan pentingnya untuk melakukannya secara alkitabiah pelayanan pekerjaan Tuhan melalui paduan suara.

Komitmen secara umum dapat diartikan sebagai pernyataan kehendak atau janji untuk melakukan sesuatu yang telah diputuskan dengan setia. ${ }^{47}$ Komitmen juga dapat diartikan sebagai pernyataan kehendak atau janji untuk dengan setia melakukan sesuatu yang telah diputuskan. Dengan demikian berkomitmen jelas membutuhkan pengorbanan dan pengabdian. Komitmen merupakan kebergantungan setiap manusia kepada Allah, dikarenakan manusia harus bersandar sepenuhnya pada firman dan penyertaan-Nya. Lebih lanjut dijelaskan bahwa, komitmen merupakan kebulatan hati mengabdikan diri untuk melayani-Nya, dengan segenap hati, pikiran, kekuatan, demi kecintaannya terhadap pelayanan. ${ }^{48}$

Komitmen pelayanan sebagai kebulatan hati mengabdikan diri untuk melayani Tuhan, dengan segenap hati, pikiran, kekuatan, demi kecintaannya terhadap pelayanan. Dapat disimpulkan komitmen pelayanan mengandung unsur janji, kesertaan, bahwa apa yang diputuskan itu merupakan tekat atau kebulatan hati seseorang dalam melakukan pelayanan. Dalam pengertian ini menurutnya Rasul Paulus adalah contoh yang paling sederhana untuk menjadi teladan dan

${ }^{47}$ Departemen Pendidikan Nasional, Kamus Besar Bahasa Indonesia Pusat Bahasa (Jakarta: PT Gramedia Pustaka Utama, 2014), 719.

${ }^{48}$ L. Suharti, Pengaruh Servant Leadership Kepemimpinan Melayani terhadap Motivasi Pelayanan dan Dampaknya pada Komitmen Pelayanan (Salatiga: Universitas Kristen Satya Wacana, 2013), 3-4. panutan dalam pelayanannya. Lebih lanjut dijelaskan mengacu pada Rasul Paulus maka komitmen dalam pelayanan adalah suatu keharusan atau wajib hukumnya karena sejatinya, (1) komitmen adalah dasar bagi seseorang untuk terlibat dalam pelayanan dan (2) kesetiaan seseorang dalam pelayanan tergantung bagaimana orang tersebut memegang komitmennya di hadapan Allah.

Dari uraian diatas penulis menyimpulkan bahwa Dampak Integritas Berperilaku Kudus Terhadap Komitmen dalam Pelayanan Suara Adonai merupakan perjanjian untuk melakukan sesuatu baik dengan diri sendiri, orang lain atau juga suatu organisasi (gereja) untuk kemuliaan Tuhan lewat pujian dan penyembahan. Berkomitmen jelas membutuhkan pengorbanan dan pengabdian sehingga komitmen berarti kebergantungan setiap manusia kepada Allah.

\section{KESIMPULAN}

Berdasarkan paparan yang telah dikemukakan, maka dapat diambil kesimpulan sebagai berikut: Pertama, Integritas Berperilaku Kudus yaitu; Integritas merupakan gambaran seorang pribadi yang memiliki kualitas diri dalam segala dimensi kehidupannya. Seorang yang berintegritas memiliki pikiran yang utuh (cerdas, dalam dan luas), emosi yang stabil, kemauan yang teguh, tidak mudah menyerah, mampu berbagi hidup dengan orang lain, menaati aturan yang ada, 
berfokus pada nilai-nilai luhur agama dan kemanusiaan. Kudus atau kekudusan merupakan suatu sifat orang atau sesuatu yang sepenuhnya sesuai dengan tujuan atau maksud keberadaannya yang bulat dan utuh.

Kedua, Dari uraian diatas penulis menyimpulkan bahwa Integritas Berperilaku Kudus dalam Menciptakan Pelayan Tuhan yang Tidak Menuruti Hawa Nafsu, Hidup dalam Takut akan Tuhan, dan Berperilaku Taat Kebenaran. Hawa nafsu adalah sistem duniawi yang bertentangan dengan rencana Allah bagi semua ciptaanNya, hawa nafsu bukan hanya sensual impuls dan keinginan, tetapi keinginan apa yang berbeda dari apa yang Tuhan ijinkan, keinginan jahat. Takut berarti kepanikan, ketakutan dalam menghadapi peristiwa yang tidak dimengerti, rasa takut sebagai sikap dasar terhadap Allah dan dalam hubungan ilahi dalam arti penghormatan dan merupakan akhir dari kecemasan sebelum menerima ancaman dan hukuman. Ketaatan kepada kebenaran yang Petrus bicarakan adalah penyampaian awal untuk mengklaim Injil. Dalam iman yang menyelamatkan, kebenaran Allah yang didengar dan diperhatikan. "Ketaatan" disebutkan sebagai kualitas dari anak yang taat kepada Allah, yang konsisten seperti ketaatan Yesus Kristus.

Ketiga, Dampak Integritas Berperilaku Kudus Terhadap Komitmen dalam Pelayanan Suara Adonai merupakan perjanjian untuk melakukan sesuatu baik dengan diri sendiri, orang lain atau juga suatu organisasi (gereja) untuk kemuliaan Tuhan lewat pujian dan penyembahan. Berkomitmen jelas membutuhkan pengorbanan dan pengabdian sehingga komitmen berarti kebergantungan setiap manusia kepada Allah.

\section{DAFTAR PUSTAKA}

Allen Walker Read, The New International Webster's Comprehensive Dictionary of the English Language. Napies, Florida: Trident Press International, 2003.

Baker, David L. Mari Mengenal Perjanjian Lama. Jakarta: BPK Gunung Mulia, 2002.

Bangun, Yosafat. Integritas Pemimpin Pastoral. Yogyakarta: ANDI, 2010.

Bolander, Donald O. New Webster's Dictionary and Thesaurus of the English Language. New York: Lexicon Publications INC, 1991.

Bungin, Burhan. Metodologi Penelitian Sosial Format-format Kuantitatif dan Kualitatif. Surabaya: Airlangga University Press, 2001.

Carter, Stephen L. Integritas. Jakarta: Pustaka Sinar Harapan, 1999.

Cedar, P. A., \& Ogilvie, L. J. Vol. 34: The Preacher's Commentary Series, Volume 34: James/1 \& 2 Peter/Jude. Nashville, Tennessee: Thomas Nelson Inc, 1984.

Departemen Pendidikan Nasional, Kamus Besar Bahasa Indonesia Pusat Bahasa. Jakarta: Gramedia Pustaka Utama, 2014.

Douglas, J.D. Ensiklopedia Alkitab Masa Kini. Jakarta: Yayasan Bina Komunikasi, 2009.

Elliott, J. H. 1 Peter: A New Translation with Introduction and Commentary. New Haven, London: Yale University Press, 2008.

Erickson, Millard J. Teologi Kristen Volume Satu. Malang: Gandum Mas, 2005.

Evans, Tony. Teologi Allah Allah kita Maha Agung. Malang: Gandum Mas, 1999.

Friberg, Barbara and Neva F. Mille, Analytical Greek Lexicon (Trafford Publishing, 2005). Bible Works 8 [CD-ROOM] 
Harris, Theological Dictionary of the Old Testament (Eerdmans: Abridged edition, 1985). Bible Works 8 [CDROOM]

Herdiansyah, Haris. Metodelogi Penelitian Kualitatif Seni Dalam Memahami Fenomena Sosial. Jakarta: Salemba Humanika, 2009.

Houser, Charles. Alkitab Edisi Studi. Jakarta: Lembaga Alkitab Indonesia, 2010.

Kittel, Gerhard. Theological Dictionary of the New Testament (Eerdmans: Abridged edition, 1985). Bible Works 8 [CD-ROOM]

Lamb, Jonathan. Integritas Memimpin di Bawah Pengamatan TUHAN. Jakarta: Literatur Perkantas, 2008.

Lange, J. P., Schaff, P., Fronmller, G. F. C., \& Mombert, J. I A Commentary on the Holy Scriptures: 1 Peter. Bellingham, WA: Logos Research Systems, Inc, 2008.

Lassor W.S. \& F.W. Bush, Pengantar Perjanjian Lama 1. Jakarta: BPK Gunung Mulia, 2005.

MacArthur, J. 1 Peter. Chicago: Moody Publishers, 2004.

Naude, Jackie A. Dictionary of old Testament Theology \& Ekesegesis. Paternoster Press, 1996.
O'Collins, Gerald \& Edward G, Kamus Teologi. Yogyakarta: Kanisius, 1996.

Olson, Leanne M. The Relationship Between Moral Integrity, Psychological Well-Being, and Anxiety, dalam http://www.charis.wlc.edu/publicatio ns/charis_spring02/0lson.pdf.

Read, Allen Walker. The New International Webster's Comprehensive Dictionary of the English Language. Napies, Florida: Trident Press International, 2003.

Salim, Peter, dan Yenny Salim, Kamus Bahasa Indonesia Kontemporer. Jakarta: Modern English Press, 1995.

Schlegel, Stuart A. Penelitian Grounded dalam Ilmu-Ilmu Sosial. Surakarta: FISIP UNS, 1984.

Schneider, Balz. Exegetical Dictionary of the New Testament (Eerdmans: Abridged edition, 1985). Bible Works 8 [CD-ROOM].

Sugiyono, Metode Penelitian Pendidikan Pendekatan Kuantitaif, Kualitatif dan $R \& D$. Bandung: Alfabeta, 2010.

Suharti, L. Pengaruh Servant Leadership Kepemimpinan Melayani terhadap Motivasi Pelayanan dan Dampaknya pada Komitmen Pelayanan. Salatiga: Universitas Kristen Satya Wacana, 2013. 